Article

\title{
Evaluating Insulation, Glazing and Airtightness Options for Passivhaus EnerPHit Retrofitting of a Dwelling in China's Hot Summer-Cold Winter Climate Region
}

\author{
Chenfei Liu *, Stephen Sharples (D) and Haniyeh Mohammadpourkarbasi
}

Citation: Liu, C.; Sharples, S.; Mohammadpourkarbasi, $\mathrm{H}$. Evaluating Insulation, Glazing and Airtightness Options for Passivhaus EnerPHit Retrofitting of a Dwelling in China's Hot Summer-Cold Winter Climate Region. Energies 2021, 14 , 6950. https://doi.org/10.3390/ en14216950

Academic Editors: Joao Miguel

C. Sousa, Paulo Tavares and Hermano Bernardo

Received: 25 September 2021 Accepted: 20 October 2021 Published: 22 October 2021

Publisher's Note: MDPI stays neutral with regard to jurisdictional claims in published maps and institutional affiliations.

Copyright: (C) 2021 by the authors Licensee MDPI, Basel, Switzerland. This article is an open access article distributed under the terms and conditions of the Creative Commons Attribution (CC BY) license (https:// creativecommons.org/licenses/by/ $4.0 /)$.
School of Architecture, University of Liverpool, Liverpool L69 7ZN, UK; Steve.Sharples@liverpool.ac.uk (S.S.); Haniyeh.MPK@liverpool.ac.uk (H.M.)

* Correspondence: pscliu10@liverpool.ac.uk

\begin{abstract}
Passivhaus EnerPHit is a rigorous retrofit energy standard for buildings, based on high thermal insulation and airtightness levels, which aims to significantly reduce building energy consumption during operation. However, extra retrofit materials are required to achieve this standard, which raises a contradiction between how to balance the environmental impacts of the retrofitting material inputs and extremely low energy consumption after retrofit. This motivated the analysis in this paper, which aimed to evaluate the possibilities of reducing the required retrofitting material inputs when trying to achieve the EnerPHit energy standard using a typical suburban dwelling in China's hot summer-cold winter climate region as a case study. Firstly, how the insulation performance of each envelope component affected the building's energy consumption was analysed. Based on this, sensitivity simulations of combinations of different insulation levels with different fabric components were investigated under four scenarios of insulation levels, airtightness and glazing choice. The final proposed retrofitting plans achieved the EnerPHit standard with insulation materials' savings between $18 \%$ to $58 \%$ compared to a baseline retrofit plan, and this led, in turn, to 3.9 to 12.6 tonnes of carbon reductions. Moreover, an energy-saving of $87 \%$ in heating and $70 \%$ in cooling was achieved compared with the pre-retrofit dwelling.
\end{abstract}

Keywords: Passivhaus EnerPHit standard; energy retrofitting; building envelope; parametric analysis; energy efficiency

\section{Introduction}

Against the background of climate change and resource exhaustion, improving the energy efficiency of buildings has been recognised as a method that has great potential for intervention. This is because buildings, together with the construction industry, consume about $36 \%$ of global energy production and are responsible for approximately $39 \%$ of global carbon emissions [1]. Research relating to building energy efficiency has been receiving increased attention in China in recent years, especially regarding the energy retrofitting of existing buildings. The reason for this is that older buildings account for a large proportion of the building stock, and they were built with poor standards of energy-efficient design and technology in most cases [2]. Thus, their inadequate energy performance has placed tremendous pressures on energy resource conservation [3].

Currently, urban residents in China account for around 54\% of the total population, and most of them live in high-rise buildings, where energy retrofit could be applied as part of large-scale refurbishment programmes. Thus, more importance has been attached by the Chinese government to urban buildings, as reflected in the current building regulations [4]. However, the differences between the existing urban and non-urban living areas in China are minimal, being 259.7 and 245 billion $\mathrm{m}^{2}$, respectively, and the energy consumption of non-urban dwellings in China is about $23 \%$ of the total building sector [5]. Thus, 
retrofitting of the non-urban dwellings is crucial for the energy efficient transformation of the building sector.

For the building operational energy consumption in China, the focus of consumption has changed from the north to the south of the country in recent decades. The fastest energy growth is now in the hot summer-cold winter climate southern region. The consumption proportion of this climate region had increased rapidly, and its average annual energy consumption growth rate $(10.2 \%)$ was the greatest in the country [6]. The strong need for both active heating and cooling due to the climate conditions could be a significant reason for this energy growth. However, the thermal comfort situation in dwellings in this climate region is still not satisfactory, and many occupants in rural dwellings have to adapt themselves against the outdoor weather for most of the time. Most urban residents only select to use heating when they have a strong feeling of discomfort, such as when the indoor temperature drops below $12{ }^{\circ} \mathrm{C}$ in winter [7]. Therefore, the energy consumption in dwellings in this climate region is expected to be increasing continuously following the higher requirements and expectations in thermal comfort, especially for those in rural areas. Most dwellings in the rural areas of suburban towns and villages have been largely replaced by reinforced concrete structures in the last several decades. These structures had no energy-efficient measures applied, but they are structurally sound and were intended to last for many years. Therefore, they have a great potential for energy savings from high standard energy retrofitting. The Chinese building energy conservation regulations and guidelines have been continuously updated, and the development of new technologies, and a substantial need for retrofitting, are clear. Retrofitting the existing dwellings towards relatively high energy efficiency criteria is a better solution than retrofitting several times in the building's lifetime to meet incrementally updated regulations [8].

The German Passivhaus EnerPHit standard [9] is an example of a very rigorous retrofit approach that aims to achieve significant energy savings without impairing indoor thermal comfort during building operation. In China, the Passivhaus standard is a relatively new concept, and most cases that have aimed to achieve this standard are new buildings, with the potential that a large proportion of energy savings could be achieved. For example, the first residential Passivhaus built in southern China achieved $90 \%$ energy savings in operation compared with conventional dwellings [10]. A reduction of $96 \%$ in heating energy was observed in a high-rise residential building retrofitted to the Passivhaus standard in northern China [11]. Most current Chinese Passivhaus cases were designed to simply achieve the Passivhaus energy goal. Little attention has been given to the impact and choice of individual measures, such as thermal insulation thickness or glazing choice, when considering a retrofit scheme. By considering the materials used in the retrofit, the Passivhaus energy goal may still be achieved while reducing some of the applied retrofitting measures. This approach would also reduce the costs and embodied carbon of a retrofit. The savings for a single case might be small but could be significant when considering a mass housing retrofit scenario.

For the case building in this research, a previous study by the authors [12] had proposed a retrofitting plan based on the Passivhaus concept and Chinese built Passivhaus projects experience. Retrofitting strategies included heat retention to the whole envelope and reducing air leakage, followed by using an efficient heating and ventilation system. These measures were analysed using the dynamic thermal simulation software DesignBuilder to achieve the best performance from each strategy, based on a calibrated model of the case building. The retrofitted result from that research demonstrated that the energy-saving efficiency surpassed the EnerPHit standard's requirement by $25 \%$ in heating and $16 \%$ in cooling due to over-sizing of retrofitting inputs. These results suggested that retrofitting measures could be applied more efficiently, thus achieving a better balance between the EnerPHit goal and the environmental impacts from the retrofitting materials. For Passivhaus, mechanical components for ventilation, heating or cooling systems, are necessary depending on the climate type, and the size of the system would not change unless the demand changed significantly [13]. Those systems are all necessary for regions 
with hot summer-cold winter climates, and retrofitting in such regions is more likely to focus on the fabric of the building envelope. Thus, this study explored the possibility of upgrading a building's envelope so that EnerPHit criteria could be met whilst reducing the overall retrofit environmental impact.

\section{Literature Review}

Passivhaus buildings are regarded as super energy-efficient buildings, reducing energy demand by improving the building envelope's thermal and airtightness performance. Due to the super airtightness of the envelope, a mechanical ventilation system is necessary to supply fresh air and to recycle the heat from the indoor exhaust air so that the energy consumption can be further reduced [11]. The EnerPHit standard sets the matching criteria for buildings retrofitted towards the Passivhaus standard, and it has slightly different requirements in energy demand for buildings in different climates. For the studied hot summer-cold winter climate, EnerPHit's energy demand is limited to $20 \mathrm{kWh} / \mathrm{m}^{2}$ a for space heating and $15 \mathrm{kWh} / \mathrm{m}^{2} \mathrm{a}$ for space cooling, and the standard requires an insulation performance in which the $U$-value of the entire opaque envelope is no greater than $0.3 \mathrm{~W} / \mathrm{m}^{2} \mathrm{~K}$ [9]. Moreover, as the transparent areas in a façade can be a weak point for the thermal envelope, Passivhaus EnerPHit requires windows with particularly low U-values of around $0.7 \mathrm{~W} / \mathrm{m}^{2} \mathrm{~K}$ to $0.85 \mathrm{~W} / \mathrm{m}^{2} \mathrm{~K}$ [14]. Therefore, the energy consumption required by EnerPHit is much lower than that of traditional buildings in the same climate due to the coordination of all the energy-saving measures [12]. There are many global examples of Passivhaus buildings, such as in Sweden [15], the UK [16], Austria [17], Brazil [18] and China [19], which have all demonstrated that large amounts of energy could be saved by achieving this standard.

However, for achieving the strict energy criteria of Passivhaus and EnerPHit, significant adaptations to the entire envelope fabric, airtightness and mechanical systems of the building are involved, which is considered challenging, especially in retrofitting cases [11]. Therefore, meeting the Passivhaus standard involves extra materials to attain the criteria successfully [20]. In contrast, the manufacture of those extra materials can consume a large amount of energy and causes significant carbon emissions, which are expected to be factored into the construction process of Passivhaus buildings [20]. For example, a life cycle study of a Belgian Passivhaus suggested the embodied energy, which is the energy used for a material's production, could represent $40-56 \%$ of the building's total energy consumption over 100 years, lifetime [21]. A similar study of a Chinese Passivhaus hotel building found that the embodied energy accounted for $24.3 \%$ of the total energy demand over a 70-year lifespan, and that this demand was about $42 \%$ higher than the embodied energy if the building had been constructed according to the local building regulation requirements [10]. A comprehensive analysis of building lifetime carbon distributions based on 238 cases globally found the share for embodied carbon was changed from the average value of $20-25 \%$ in buildings built with current regulations to $45-50 \%$ in high energy efficiency buildings, and in extreme cases, the share could up to $90 \%$. From a more detailed analysis of those energy-efficient buildings, this research highlighted the fact that the total carbon emission was higher in some super energy-efficient buildings than less efficient ones, because the embodied carbon of extra building materials was unable to be traded off against the carbon saved during operation. This confirms the need to address and reduce the embodied carbon in order to meet the goal of overall carbon reduction in a building's lifetime [22]. The embodied carbon is particularly significant for highly energy-efficient buildings like Passivhaus, but currently, the embodied impact is not included in its criteria $[23,24]$.

It would be very beneficial if the retrofit embodied energy could be minimised whilst still achieving the operational energy savings from the EnerPHit retrofitting measures. This raises the need to identify the suitable insulation properties of each envelope element and the combination of the envelope elements to balance the retrofitting inputs and the energy-saving effort after retrofit [25]. Sensitivity analysis is a standard method for 
assessing suitable combinations for various aims. A study about Passivhaus within the Portuguese climate performed a sensitivity analysis to ascertain the combinations of four parameters with different sub-options. Some 96 combinations were simulated, and the optimal combination led to reductions of $62 \%$ and $72 \%$ in heating and cooling energy, respectively [26]. A similar sensitivity analysis was completed to detect the combination with the lowest energy demand [26].

Airtightness performance is an uncertainty when selecting envelope component combinations because it is highly correlated with the volume of warm/cool air transfer through the envelope and thus affects the entire envelope's thermal performance [27]. The lower the envelope infiltration rate is, the more effectively the ventilation system can recover the heat from the indoor air in Passivhaus. However, the actual level of airtightness is often measured by a blower door test conducted on-site after the construction is completed [28]. Thus, the airtightness level remains unknown during the retrofitting solution planning stage. Achieving a low envelope infiltration rate requires skilled and careful construction techniques, such as sealing of joints in the envelope components and taping the penetrations across the envelope due to pipes or other necessary construction [14]. Many Passivhaus buildings have attained a better airtightness level than the required level of 0.6 air changes per hour (ach) for new builds and 1.0 ach for retrofits. For instance, a Passivhaus in London had an airtightness rate of 0.44 ach [16], while an average airtightness rate of 0.37 ach was tested for 52 Passivhaus cases in Germany [29]. However, it is much more difficult to attain such a low infiltration rate in retrofitting buildings due to the restrictions on the redevelopment of existing structures. For this reason, assessing the minimum airtightness performance that can be allowed in EnerPHit standard retrofitting cases, and how it affects the other retrofitting measures, is an interesting topic.

Therefore, this study used DesignBuilder, a dynamic thermal simulation software, to investigate parametrically the effect of changing envelope insulation and airtightness levels on meeting EnerPHit energy requirements. Then, sensitivity simulations were undertaken to analyse the retrofitting solutions for four possible envelope scenarios for a case study building, with the aim of reducing retrofitting inputs from a baseline retrofit plan whilst achieving the EnerPHit standard.

\section{Research Method}

\subsection{Case Study}

The case building for this study (Figure 1) was a semi-detached reinforced concrete residential/commercial building located in the small town of Huilong in the southwest of Hunan province. The case building has four storeys, with the ground floor rented out for commercial use, like most town dwellings in Hunan, with the upper three floors being three individual flats which each had the same layout, as shown in Figure 2. Only the residential areas, with a total floor area of $297 \mathrm{~m}^{2}$, were considered for retrofitting towards the EnerPHit standard. Therefore, the lowest envelope of the treated space is the "1st floor" instead of the ground floor. The thermal performance of the case building was considered poor because no insulation material was used in the envelope, and the windows were single glazed. The airtightness level was estimated to be 3 ach, based on a previous study [12], and Table 1 gives the construction details of each envelope component and their U-value. 



Figure 1. View of the Huilong case-building (photos were taken by the author) and its location on the China climate zone map, map sourced from [30].

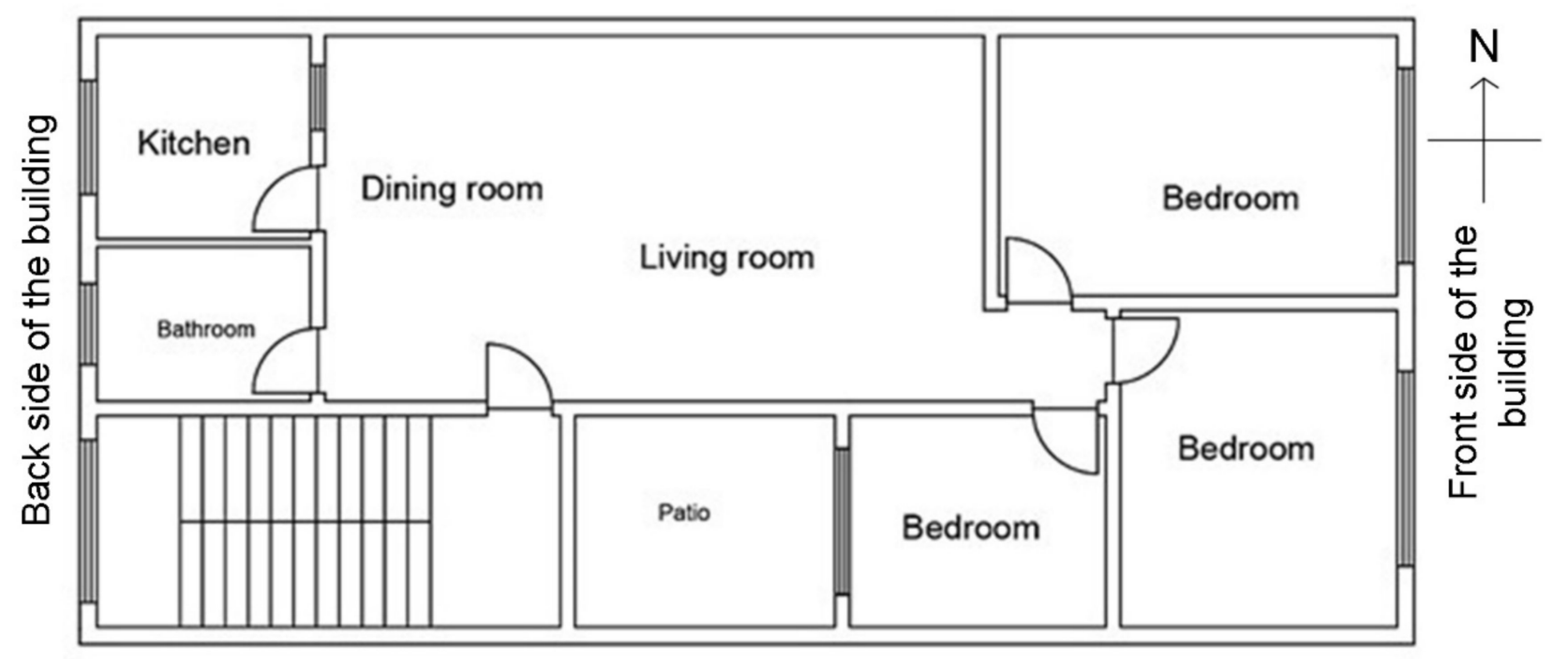

Figure 2. Floor plan of the case building, adapted from [12]. 
Table 1. The original construction details of the case building and the U-values before and after envelope insulation retrofitting adapted from [12].

\begin{tabular}{|c|c|c|c|c|}
\hline Item & Construction Detail & $\begin{array}{l}\text { Original U-Values } \\
\left(\mathrm{W} / \mathrm{m}^{2} \mathrm{~K}\right)\end{array}$ & $\begin{array}{c}\text { Insulation } \\
\text { Material }\end{array}$ & $\begin{array}{l}\text { Baseline Retrofit } \\
\text { U-Values }\left(\mathrm{W} / \mathrm{m}^{2} \mathrm{~K}\right)\end{array}$ \\
\hline Exterior wall & $\begin{array}{l}5 \mathrm{~mm} \text { putty paint, } 10 \mathrm{~mm} \\
\text { cement mortar, } 180 \mathrm{~mm} \text { clay } \\
\text { brick, } 10 \mathrm{~mm} \text { cement mortar, } \\
10 \mathrm{~mm} \text { outside porcelain tiles }\end{array}$ & 2.32 & 250 mm Rock wool & 0.125 \\
\hline Interior wall & $\begin{array}{l}5 \mathrm{~mm} \text { putty paint, } 10 \mathrm{~mm} \\
\text { cement mortar, } 180 \mathrm{~mm} \text { clay } \\
\text { brick, } 10 \mathrm{~mm} \text { cement mortar, } \\
5 \mathrm{~mm} \text { putty paint }\end{array}$ & 2.30 & No insulation & 2.30 \\
\hline Roof & $\begin{array}{c}50 \mathrm{~mm} \text { cement, } 100 \mathrm{~m} \\
\text { reinforced concrete raft, } \\
400 \text { mmair gap, } 10 \mathrm{~mm} \text { wood } \\
\text { board, } 5 \mathrm{~mm} \text { putty paint }\end{array}$ & 1.90 & 250 mm Rock wool & 0.123 \\
\hline Internal and 1st floors & $\begin{array}{l}10 \mathrm{~mm} \text { porcelain tiles, } 10 \mathrm{~mm} \\
\text { cement, } 50 \mathrm{~mm} \text { cement mortar, } \\
100 \mathrm{~m} \text { reinforced concrete raft, } \\
5 \mathrm{~mm} \text { putty paint }\end{array}$ & 2.44 & 250 mm Rock wool & 0.126 \\
\hline Windows & $\begin{array}{l}4 \mathrm{~mm} \text { single glass, Aluminium } \\
\text { window frame }\end{array}$ & 5.85 & Triple glazed LoE & 0.78 \\
\hline
\end{tabular}

\subsection{Climate}

Hunan province is situated in the hot summer-cold winter climate zone in China. The average temperatures of the coldest month are usually between 4 to $8{ }^{\circ} \mathrm{C}$, and the average temperatures in the hottest month are between 27 to $30^{\circ} \mathrm{C}$ [31].

For this study, local climate data were recorded around the case study building for one year between July 2018 and June 2019. The recorded weather data are summarised in Figure 3, which illustrates the local weather conditions and the corresponding indoor temperature and humidity situation of the case building when no active heating/cooling methods were used in the dwelling. The outdoor monthly mean temperatures varied from $6.2^{\circ} \mathrm{C}$ to $31.1^{\circ} \mathrm{C}$ in the recorded year, with the monthly average high temperature of $37.7^{\circ} \mathrm{C}$ in July and average low temperature of $4.5^{\circ} \mathrm{C}$ in January. The outdoor recorded highest and lowest temperatures were more extreme, as the values were $41.1^{\circ} \mathrm{C}$ and $-0.3{ }^{\circ} \mathrm{C}$, respectively. Compared with the outdoor temperature, the indoor temperatures were more stable but not enough to be comfortable. The indoor monthly mean temperature was always higher than the outdoor situation and varied between $6.6{ }^{\circ} \mathrm{C}$ to $32.3{ }^{\circ} \mathrm{C}$, with the highest monthly average temperature of $33.1^{\circ} \mathrm{C}$ in July and a lowest average temperature of $6.3^{\circ} \mathrm{C}$ in January. Both indoor and outdoor relative humidity had comparatively high values, with the winter months being more humid than the summer months. The monthly mean relative humidity levels were between $69 \%$ and $89 \%$ outdoors and between $61 \%$ and $88 \%$ indoors.

Overall, the recorded data suggested the location of the case building had a typical hot summer-cold winter climate, with a relatively high humidity level all year round. The indoor thermal comfort level was considered unsatisfactory, especially in the summer and winter months, when the building is under free-running condition. 


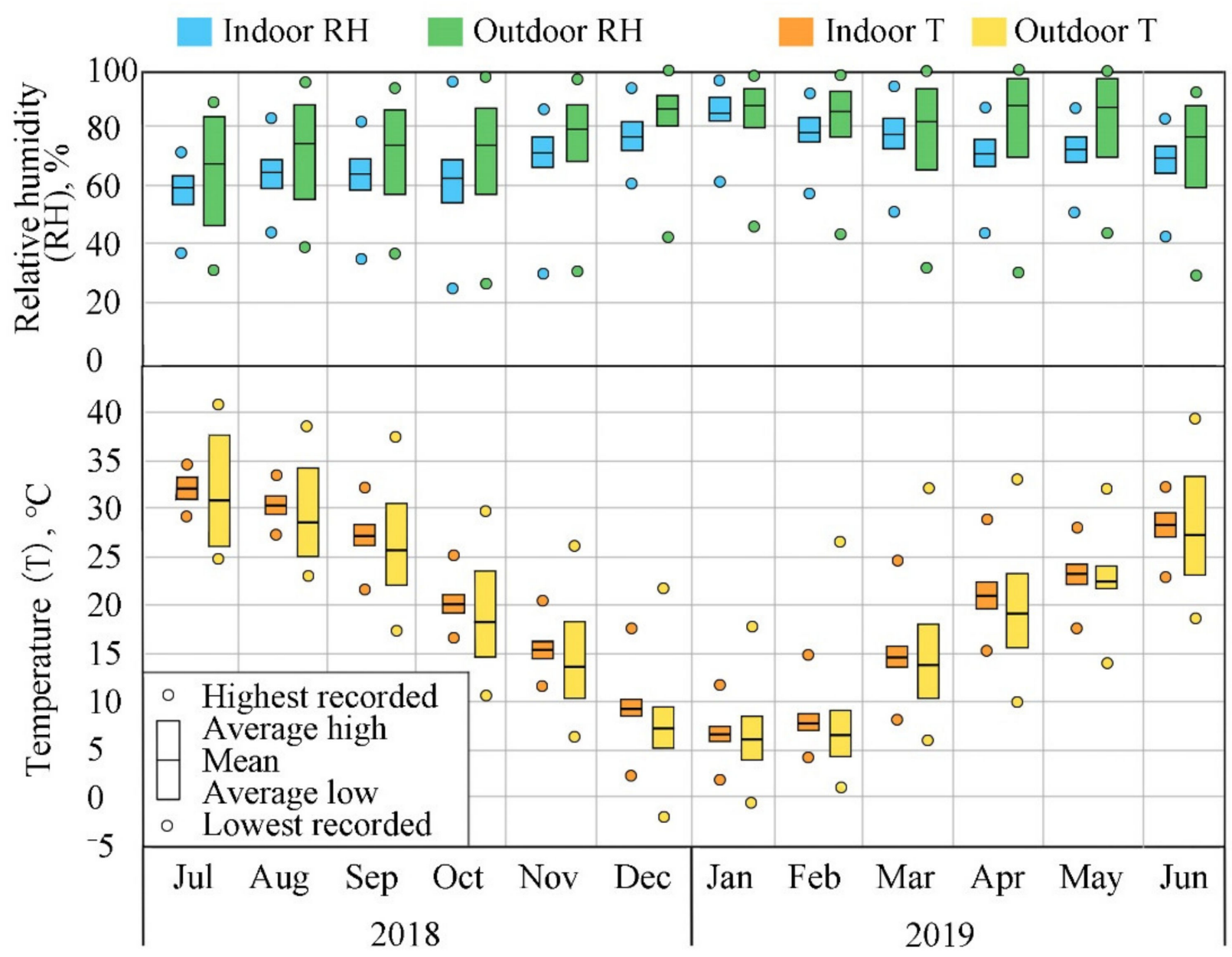

Figure 3. The recorded indoor and outdoor measured air temperature and relative humidity data for the one-year period July 2018 to June 2019.

\subsection{Short Review of the Previous Research}

A previous analysis of the case building [12] suggested an annual heating demand of $150.6 \mathrm{kWh} / \mathrm{m}^{2} \mathrm{a}$ and cooling demand of $42 \mathrm{kWh} / \mathrm{m}^{2}$ a under the pre-retrofit status. Then, a simulated retrofitting process was carried out, which involved insulating the entire envelope with $250 \mathrm{~mm}$ of Rockwool, improving the airtightness level to 0.6 ach and adopting a mechanical ventilation system with a sensible and latent heat recovery efficiency of $85 \%$ and $80 \%$, respectively. The coefficient of performance (CoP) of the heating system was improved from 1.0 to 1.2 , and the $\mathrm{CoP}$ of the cooling system remained at the value of 1.8. Passive cooling methods of window shading and natural ventilation were also analysed and the most efficient methods were adopted for the case building. The energy demands for both pre-retrofit and retrofitted cases were simulated with a heating and cooling setpoint of $20^{\circ} \mathrm{C}$ and $25^{\circ} \mathrm{C}$, respectively, to be in line with the EnerPHit standard required comfort temperature range, while no limitation was put on the indoor relative humidity. As a result of these retrofitting measures, the achieved final energy demand was $14.9 \mathrm{kWh} / \mathrm{m}^{2} \mathrm{a}$ and $11.5 \mathrm{kWh} / \mathrm{m}^{2} \mathrm{a}$ for heating and cooling, respectively, which surpassed the EnerPHit requirement of $20 \mathrm{kWh} / \mathrm{m}^{2}$ a and $15 \mathrm{kWh} / \mathrm{m}^{2} \mathrm{a}$. As mentioned earlier, this study evaluates the possibilities of reducing the retrofitting inputs, and this retrofitted case was used as the baseline retrofit case for DesignBuilder simulations.

\subsection{Research Workflow}

The overall research workflow is demonstrated in Figure 4. All the energy simulations were performed using DesignBuilder (version 6.1.3) [32]. The weather file used in Design- 
Builder simulations was generated by the climate database software Meteonorm using a source from the closest weather station to the case building, located in Wugang.

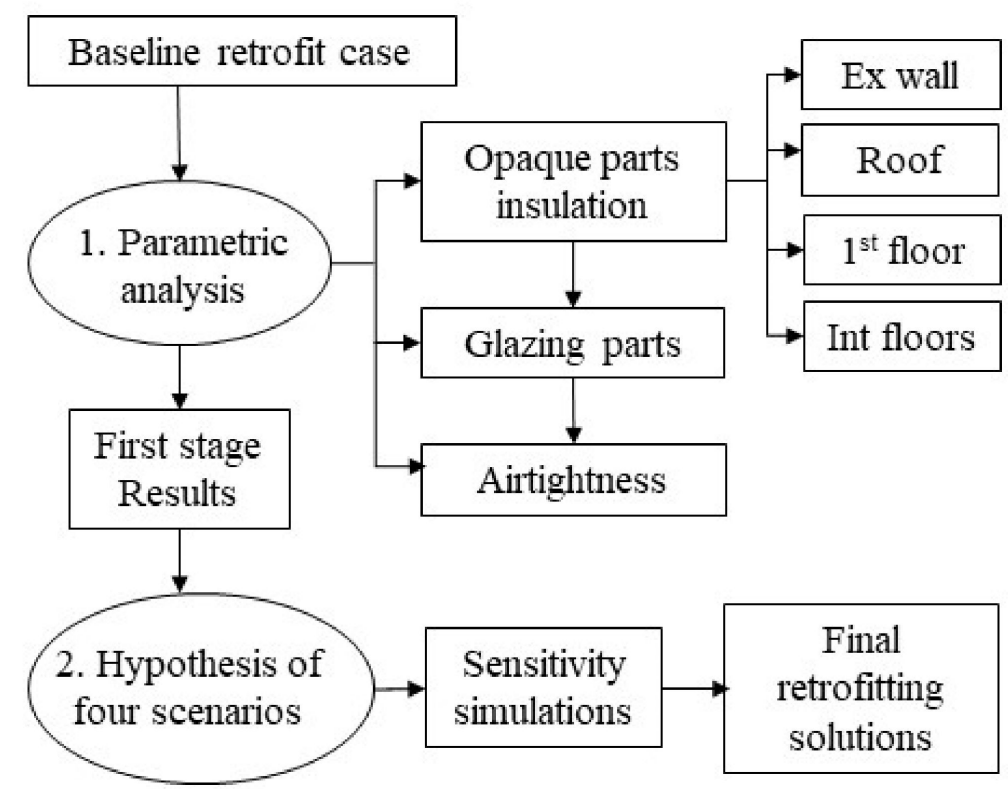

Figure 4. Workflow of the study.

In the first stage of the research, a series of parametric analyses were undertaken to evaluate the sensitivity of the insulation performance of each envelope component towards the building's energy consumption. The evaluated parameters included the exterior wall, roof, 1st floor, interior floors, and windows. Envelope airtightness level was also investigated due to its significant effect on energy consumption. For the opaque components, the insulation performance was examined according to various thicknesses of insulation layers, from a relatively thin layer of $50 \mathrm{~mm}$, to the baseline retrofit model adopted thickness of $250 \mathrm{~mm}$, and with a simulation step of $25 \mathrm{~mm}$, which is the thinnest thickness of Rockwool insulation board that most local suppliers provide. Materials other than Rockwool were not considered in the parametric analysis because the primary intent was to evaluate the relationship between the envelope thermal transmittance and building energy consumption, and different insulation materials could achieve the same thermal performance with different usage amounts.

The thermal performance of the windows was assessed with two points of focus-the U-value and the solar heat gain coefficient (SHGC). For the airtightness level, the studied range was from the EnerPHit standard maximum allowed value of 1.0 ach to the value adopted in the baseline retrofit model, 0.6 ach. Airtightness levels better than 0.6 ach were not examined, given the restrictions of the existing structure. As a result, the analysis results should provide evidence about the parameters that could heavily influence energy consumption worth retaining for high thermal performance. Conversely, those parameters which did not strongly influence thermal performance could be reduced.

In the second stage of the research, four scenarios of retrofitting measures were hypothesized, and retrofitting plans were analysed for these four scenarios. Combinations of different retrofitting measures were examined through sensitivity simulations, and the combinations most suited to achieve the EnerPHit standard with the lowest level of insulation material inputs were considered as the final retrofitting solution. The combinations for simulation were based on the parametric analysis results in which the impact of envelope components on building energy consumption was indicated. Then, the sensitivity simulations were progressed in a way that small changes in insulation thickness were made based on energy demand results of the previously tested combinations until the combination most close to the research purpose was found under each scenario. The final 
combinations found under the four scenarios were considered as improved retrofitting solutions because different amounts of insulation inputs could be saved compared with the baseline retrofit case.

\section{Results}

\subsection{Stage 1: Parametric Analysis \\ 4.1.1. Opaque Envelope Components}

Table 2 illustrates the U-values of each of the opaque envelope measures in the range of Rockwool insulation thicknesses that were considered for testing, and the impact on the building's heating demand $(\mathrm{H})$ and cooling demand $(\mathrm{C})$ are displayed in Figure 5.

Table 2. Opaque components' U-value $\left(\mathrm{W} / \mathrm{m}^{2} \mathrm{~K}\right)$ for different thicknesses of Rockwool insulation.

\begin{tabular}{|c|c|c|c|c|c|c|c|c|c|}
\hline Insulation Thickness & $50 \mathrm{~mm}$ & $75 \mathrm{~mm}$ & $100 \mathrm{~mm}$ & $125 \mathrm{~mm}$ & $150 \mathrm{~mm}$ & $175 \mathrm{~mm}$ & $200 \mathrm{~mm}$ & $225 \mathrm{~mm}$ & $250 \mathrm{~mm}$ \\
\hline & \multicolumn{9}{|c|}{ U-Values $\left(\mathrm{W} / \mathrm{m}^{2} \mathrm{~K}\right)$} \\
\hline External wall & 0.516 & 0.317 & 0.290 & 0.238 & 0.201 & 0.175 & 0.154 & 0.138 & 0.125 \\
\hline Roof & 0.495 & 0.36 & 0.283 & 0.233 & 0.198 & 0.172 & 0.152 & 0.137 & 0.124 \\
\hline 1st floor & 0.530 & 0.378 & 0.294 & 0.240 & 0.203 & 0.176 & 0.155 & 0.139 & 0.126 \\
\hline Internal floor & 0.530 & 0.378 & 0.294 & 0.240 & 0.203 & 0.176 & 0.155 & 0.139 & 0.126 \\
\hline
\end{tabular}

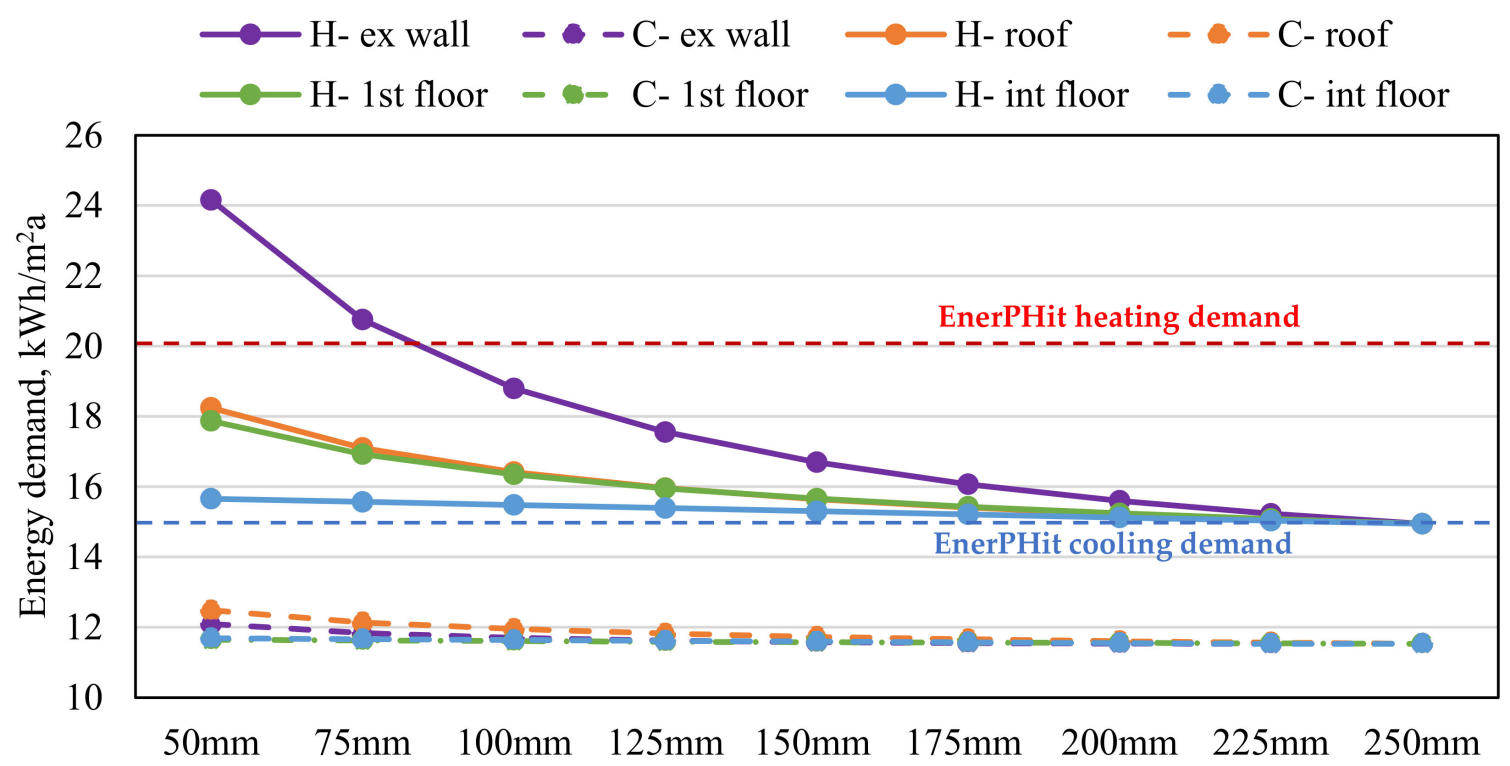

Figure 5. Parametric analysis for each opaque envelope components insulation thickness—impact on the building's heating $(\mathrm{H})$ and cooling $(\mathrm{C})$ demand.

As mentioned in Section 3.1, the parametric analysis was based on the baseline retrofit case, in which when one parameter was changed, and the others were kept the same. From Figure 5, the results show that the insulation thickness had a much greater effect on heating energy demand than on cooling energy demand. Regarding the heating demand, the effect for the exterior wall was the most significant, as the demand was decreased from $24.2 \mathrm{kWh} / \mathrm{m}^{2}$ a to $14.9 \mathrm{kWh} / \mathrm{m}^{2}$ a within the tested insulation thickness range, which is a reduction of $38 \%$. In addition, the heating energy demand exceeded the EnerPHit criteria of $20 \mathrm{kWh} / \mathrm{m}^{2} \mathrm{a}$ when the exterior wall insulation thickness was below $100 \mathrm{~mm}$. Moreover, the thermal performance of the roof had a secondary effect on heating, with the demand dropping by $3.3 \mathrm{kWh} / \mathrm{m}^{2} \mathrm{a}(18 \%)$ when the insulation thickness increased from $50 \mathrm{~mm}$ to $250 \mathrm{~mm}$, and a slightly lower impact (deduction of 17\%) was found on the 1st floor. On the 
other hand, the interior floors slabs had the least effect on heating demand as the decrease in energy demand was only $5 \%$ for the tested thickness range.

Regarding the cooling demand, the overall impacts from the thermal performance changes were much less significant. As can be seen in Figure 5, the impact from the roof was ranked first, followed by the exterior wall, 1st floor and interior floor. This result indicated that insulating the opaque components were helpful to reduce the cooling energy, while this could be achieved without necessarily thick insulation when other measures were applied.

In conclusion, the findings suggest that the heating demand was the leading factor for deciding the insulation thickness of the opaque envelope components, and the required insulation thickness for achieving the heating energy criteria was also largely able to achieve the cooling criteria. Regarding the influence of the opaque components on energy demand, a high insulation thickness value should be kept for exterior walls, and a reasonable insulation thickness should be used for the roof and 1st-floor slab. However, for the interior floor slabs, the insulation material could be entirely removed, as it had a negligible effect on both heating and cooling demand.

\subsubsection{Glazing Types}

When selecting glazing options for analysis in this study, both the glazing U-value and the solar heat gain coefficient (SHGC), which have a close relationship with the indoor heat gain/loss and the building energy consumption, were considered [33,34]. The Passivhaus standard recommends triple glazed windows to ensure that the glass internal surface temperature does not drop below $17^{\circ} \mathrm{C}$, while some research suggests that the Passivhaus standard could be met by applying double glazed windows in hot climates [26,35]. To verify this for the studied climate, ten types of glazing were examined, mostly triple glazed, except for one double glazed window with a relatively high U-value of $2.55 \mathrm{~W} / \mathrm{m}^{2} \mathrm{~K}$. The difference in yearly heating and cooling energy demand was simulated when each individual glazing type was adopted by the case building. The best performance shading method examined in the previous study, with the external blinds shading operating during May to September under a designed schedule, was modelled for all the glazing types to avoid differences in energy consumption caused by shading methods. The results are shown in Figure 6.

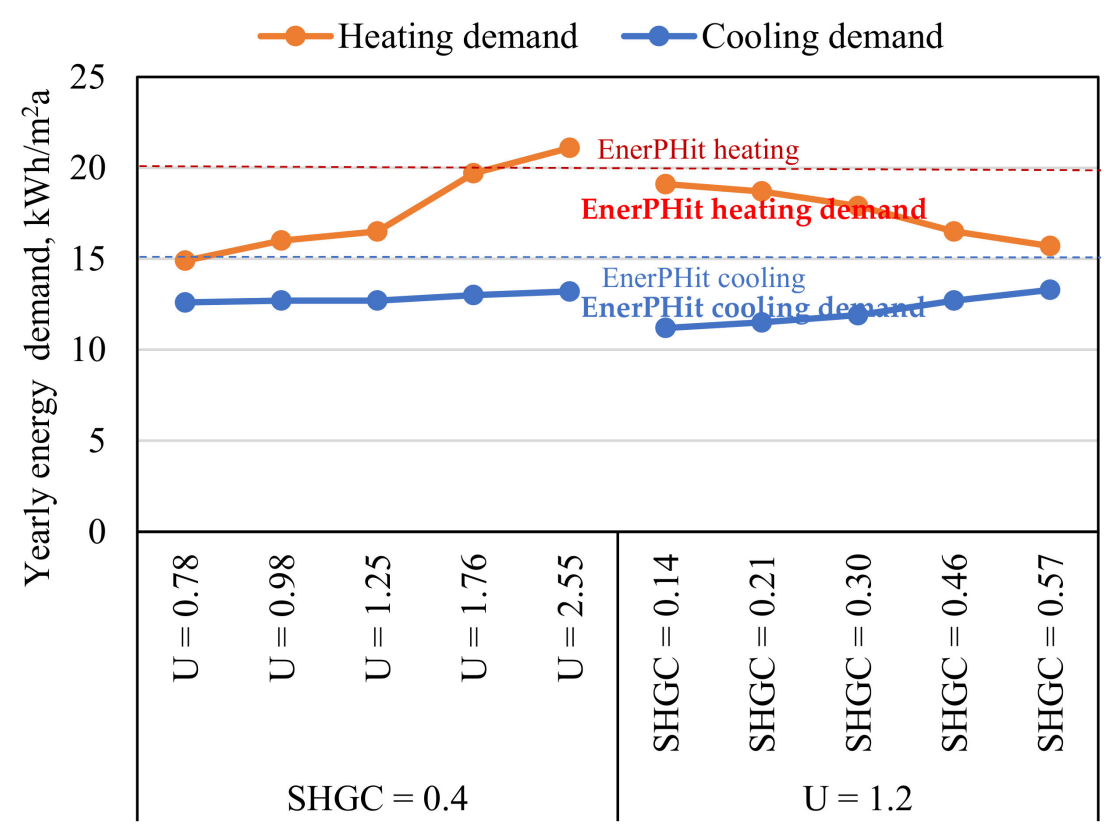

Figure 6. Parametric analysis of the impact of different U-values and SHGC glazing types on the building's heating demand and cooling demand. 
The ten types of tested glazing were divided into two groups of five, where the first group had the same fixed moderate SHGC value of 0.4 while the U-values were increased from a high performance of $0.78 \mathrm{~W} / \mathrm{m}^{2} \mathrm{~K}$ to a relatively poor performance of $2.55 \mathrm{~W} / \mathrm{m}^{2} \mathrm{~K}$ see Figure 6 (left). When using these five glazing types, the corresponding heating demand ranged from $14.9 \mathrm{kWh} / \mathrm{m}^{2}$ a to the highest of $21.9 \mathrm{kWh} / \mathrm{m}^{2} \mathrm{a}$. The heating demand rose gradually with increasing U-value until the U-value exceeded $1.25 \mathrm{~W} / \mathrm{m}^{2} \mathrm{~K}$, (a moderate performance triple glazed window), when the heating demand increased at a much greater rate. The corresponding cooling demand has a narrower range, from $11.5 \mathrm{kWh} / \mathrm{m}^{2} \mathrm{a}$ to $12.5 \mathrm{kWh} / \mathrm{m}^{2} \mathrm{a}$, with the increase in U-value having a very small impact on cooling demand until the glazing U-value rose to $2.55 \mathrm{~W} / \mathrm{m}^{2} \mathrm{~K}$ (a double glazed window). For the second group, shown on the right-hand side of Figure 6 , the five glazing types had the same moderate U-value of $1.2 \mathrm{~W} / \mathrm{m}^{2} \mathrm{~K}$ but the SHGC values were increased from 0.14 to 0.57 . The results show that the heating demand fell from $19.7 \mathrm{kWh} / \mathrm{m}^{2}$ a to $16.2 \mathrm{kWh} / \mathrm{m}^{2}$ a following the SHGC increases, while the cooling demand was increased from $10.8 \mathrm{kWh} / \mathrm{m}^{2} \mathrm{a}$ to $12.2 \mathrm{kWh} / \mathrm{m}^{2} \mathrm{a}$. Thus, the increase in SHGC negatively influenced heating energy demand and positively influenced cooling energy demand.

Therefore, the parametric analysis results suggested that the U-value of the glazing had a strong positive influence on the heating demand but a negligible effect on the cooling demand. The SHGC performance had a negative effect on heating demand, but positive effect on cooling demand. Among the examined ten glazing types, those with a U-value of $0.78 \mathrm{~W} / \mathrm{m}^{2} \mathrm{~K}$ and an SHGC value of 0.4 had the best performance for both heating and cooling. All of the tested glazing types were within the EnerPHit energy criteria, except for the double glazing type, which failed to meet the requirement for heating. This suggests that high thermal performance glazing is necessary for the hot summer-cold winter climate area. Moreover, the glazing types with a moderate SHGC value were more suitable for the case building under the studied climate, which did not cause extreme heating or cooling energy consumption.

\subsubsection{Airtightness}

The parametric analysis for building airtightness level was examined between the values of 1.0 ach and 0.6 ach for the reasons mentioned in Section 3.4. Figure 7 indicates that lowering the envelope's air leakage (i.e., lowering the air changes per hour) led to a decreasing energy trend in heating and cooling, but with different efficiencies. The heating consumption dropped gradually from $23.8 \mathrm{kWh} / \mathrm{m}^{2}$ a to $14.9 \mathrm{kWh} / \mathrm{m}^{2} \mathrm{a}$ following the airtightness change from 1.0 ach to 0.6 ach, a 37\% energy saving. Moreover, it is worth noting that when the case building was simulated with an airtightness level of 0.9 ach, the heating demand was $21.6 \mathrm{kWh} / \mathrm{m}^{2} \mathrm{a}$, which exceeds the EnerPHit standard requirement, and therefore 0.8 ach was the maximum acceptable airtightness level for meeting the heating demand criteria.

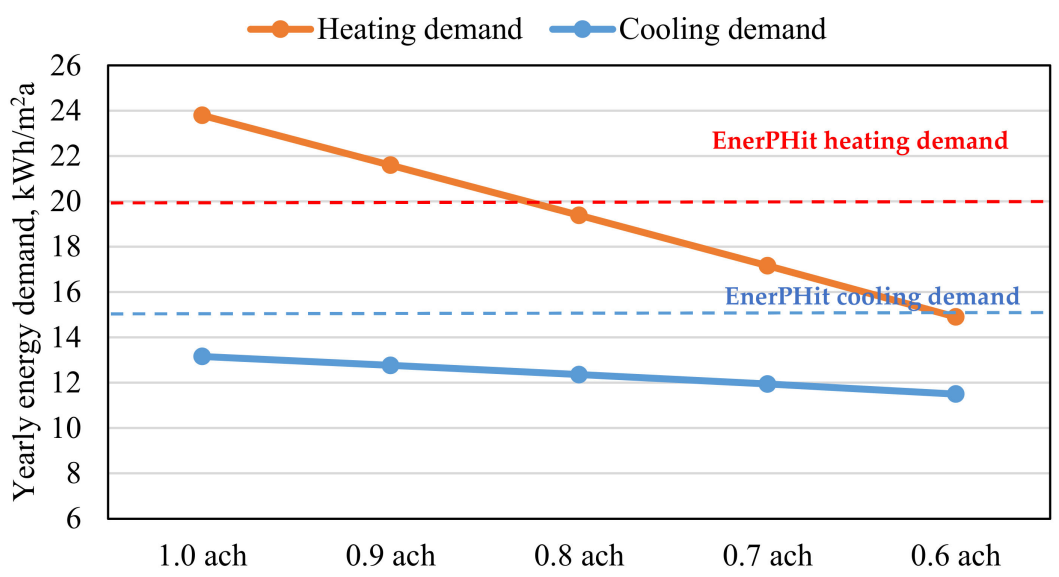

Figure 7. Parametric analysis for airtightness towards the building's heating and cooling demand. 
On the other hand, the airtightness level had a lesser effect on the cooling, as the demand changed from $13.2 \mathrm{kWh} / \mathrm{m}^{2}$ a to $11.5 \mathrm{kWh} / \mathrm{m}^{2} \mathrm{a}$, with a $13 \%$ energy saving over the tested range. The cooling demand was below the EnerPHit criteria even with the tested worst airtightness level of $1.0 \mathrm{ach}$. However, taking both heating and cooling demand into consideration, only the airtightness range between 0.8 ach and 0.6 ach was desirable to achieve the overall EnerPHit standard.

\subsection{Stage 2: Retrofitting Scenarios}

\subsubsection{Hypotheses of Four Scenarios}

The four scenarios are summarised in Table 3, and each had limitations on certain retrofit measures. In addition, the hypothesis of the four scenarios was made partly according to the parametric analysis results, such as in scenario 1, where the airtightness level of 0.8 ach was assumed to be the best achievable level because the parametric analysis result showed that the case building is not able to meet the targeted criteria with a level worse than 0.8 ach. For scenario 2, a situation was assumed that the retrofitting for all envelope parameters was reduced simultaneously from the baseline retrofit model. Similarly, an airtightness level of 0.6 ach was assumed to be realised under scenario 3 since it is the best performance considered in this study. In scenario 4 , a high performance of glazing with a U-value of $0.78 \mathrm{~W} / \mathrm{m}^{2} \mathrm{~K}$ was assumed, based on scenario 3 . According to the researchers' field investigation, this glazing value is very close with the most widely used product (U-value around $0.8 \mathrm{~W} / \mathrm{m}^{2} \mathrm{~K}$ ) in Passivhaus buildings in China. It is reasonable to suggest those scenarios for analysing the retrofitting plans, but this study only considered the retrofitting solution depending on the single factor of energy consumption. The retrofitting plans were then analysed through sensitivity simulation under the consideration of the limitations in each assumed scenario.

Table 3. The four considered scenarios for envelope performance optimisation.

\begin{tabular}{cc}
\hline & Assumed Settings for Each Scenario \\
\hline $\begin{array}{c}\text { Scenario 1 } \\
\text { Scenario 2 }\end{array}$ & $\begin{array}{r}\text { The best achievable airtightness level is assumed as } 0.8 \text { ach } \\
\text { Tcenario 3 }\end{array}$ \\
Scenario 4 & $\begin{array}{r}\text { The best achievable airtightness level is assumed as } 0.6 \text { ach. Additionally, windows are } \\
\text { assumed to have a U-value of } 0.78 \mathrm{~W} / \mathrm{m}^{2} \mathrm{~K}, \text { which is the best in the local market } \\
\text { The best achievable airtightness level is assumed as } 0.6 \text { ach. }\end{array}$ \\
\hline
\end{tabular}

\subsubsection{Sensitivity Simulation}

Under the four scenarios, combinations of envelope parameters with suitable thermal properties were tested through sensitive simulation to identify those that could achieve the EnerPHit energy standard with the minimum level of insulation material input. Due to insulating the interior floors barely helping with energy saving, it was decided not to apply insulation material to the interior floors under all scenarios. Thus, only the other five envelope parameters were considered as part of the combinations for sensitivity simulations.

Figure 8 demonstrates the sensitivity simulation results under the four scenarios, where the energy consumption of the combinations is shown in the upper part of the figures, and the corresponding thermal performance detail of insulation thickness and U-value of each of the envelope components are listed in the lower part of the figures. From the figures, it can be seen that small changes in the thermal performance of the envelope components resulted in a difference in building energy consumption. The combinations which met the EnerPHit criteria with the lowest level of insulation requirement were highlighted under each of the scenarios. Therefore, they were considered as improved retrofitting plans compared to the baseline retrofit case. For the four improved retrofitting plans, the point in common was that the insulation material was the thickest for the exterior walls, and the insulation thickness for other opaque components could be much less because the exterior wall is the parameter with the strongest connection to a building's energy demand in the studied climate. 


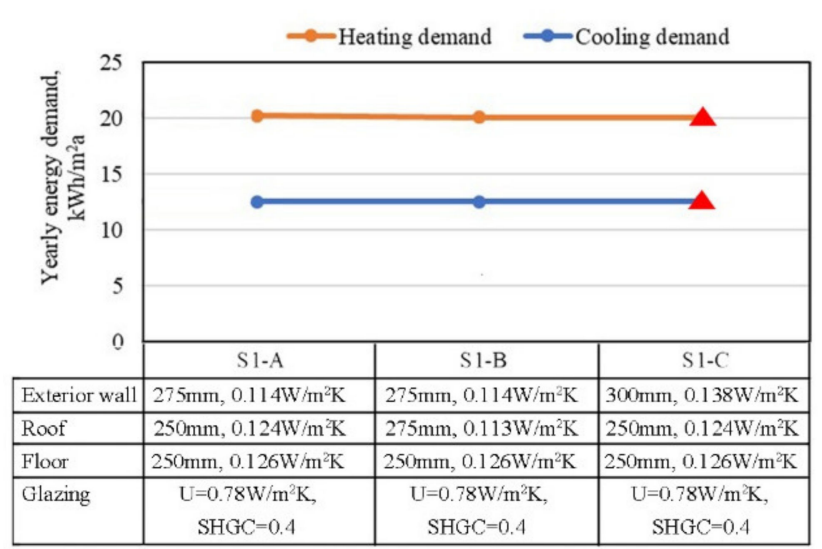

(1). Scenario 1

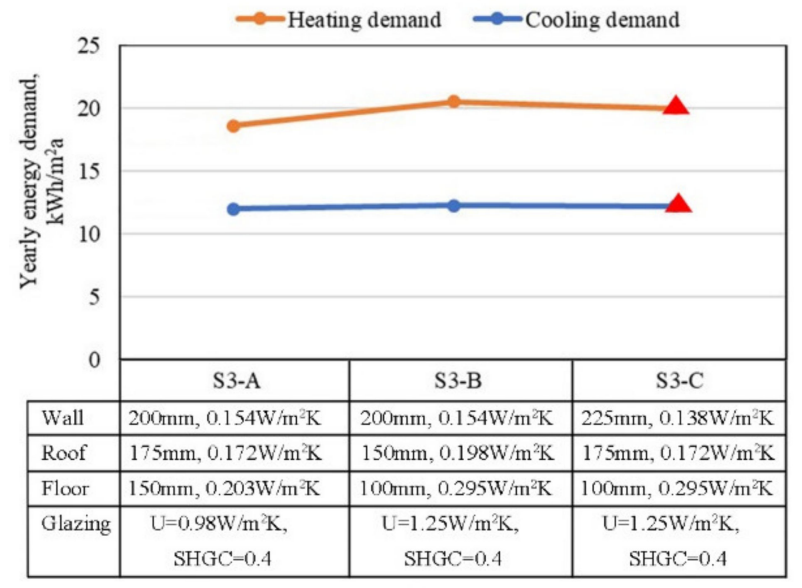

(3). Scenario 3



(2). Scenario 2

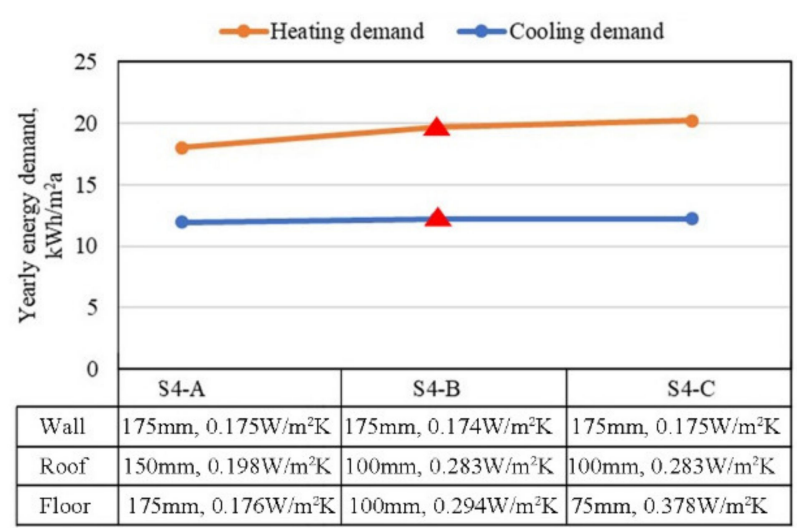

(4). Scenario 4

Figure 8. Simulated energy demands of the retrofitting combinations under the four scenarios, with the best solution marked in red.

\subsubsection{Difference between the Retrofitting Plans}

For the four improved retrofitting plans, their heating and cooling energy demands were all around $20 \mathrm{kWh} / \mathrm{m}^{2}$ a and $12 \mathrm{kWh} / \mathrm{m}^{2}$ a, respectively. However, the overall thermal properties of the improved plans were quite different for achieving the same energy performance. Table 4 lists the detail of the thermal performance of each envelope component in the improved retrofitting plans, and the thermal property of the baseline case is also listed for comparison.

Table 4. Optimal envelope thermal performance solutions under the assumed four scenarios.

\begin{tabular}{|c|c|c|c|c|c|c|}
\hline Cases & Assumptions & $\begin{array}{l}\text { Wall Insulation } \\
(\mathrm{mm})\end{array}$ & $\begin{array}{c}\text { Roof Insulation } \\
\text { (mm) }\end{array}$ & $\begin{array}{c}\text { 1st Floor } \\
\text { Insulation (mm) }\end{array}$ & $\begin{array}{l}\text { Glazing U-Value } \\
\left(\mathrm{W} / \mathrm{m}^{2} \mathrm{~K}\right)\end{array}$ & $\begin{array}{l}\text { Airtightness } \\
\text { Level (ach) }\end{array}$ \\
\hline Baseline & - & 250 & 250 & 250 & 0.78 & 0.6 \\
\hline Scenario1 & $\begin{array}{c}\text { Airtightness assumed as } \\
0.8 \text { ach }\end{array}$ & 300 & 250 & 250 & 0.78 & 0.8 \\
\hline Scenario 2 & $\begin{array}{l}\text { All insulation reduced } \\
\text { simultaneously }\end{array}$ & 250 & 175 & 150 & 0.98 & 0.7 \\
\hline Scenario 3 & $\begin{array}{c}\text { Airtightness assumed as } \\
0.6 \text { ach }\end{array}$ & 225 & 175 & 100 & 1.25 & 0.6 \\
\hline Scenario 4 & $\begin{array}{l}\text { Airtightness } 0.6 \text { ach, } \\
\text { best window type }\end{array}$ & 175 & 100 & 100 & 0.78 & 0.6 \\
\hline
\end{tabular}

Among the four scenarios, it was found that the influence of the airtightness level upon the required envelope thermal performance to meet the standard was quite distinct. 
By comparing the plans under scenarios 1 and 4, the applied gazing was the same while the airtightness performance was 0.8 ach and 0.6 ach in scenarios 1 and 4 respectively. This resulted in a dramatic difference to the opaque insulation thickness, in which the thicknesses for exterior wall, roof and 1st floor were $300 \mathrm{~mm}, 250 \mathrm{~mm}$ and $250 \mathrm{~mm}$ under scenario 1 , while in scenario 4 , the level for the same components changed to $175 \mathrm{~mm}, 100 \mathrm{~mm}$ and $100 \mathrm{~mm}$. For scenario 2, although the airtightness level and glazing performance were worse than that in the baseline retrofit case, the retrofitting solution with a lower insulation level in the roof $(175 \mathrm{~mm})$ and 1st floor $(150 \mathrm{~mm})$ managed to reach the EnerPHit standard. Comparing scenarios 3 and 4, which had the same standard of airtightness performance, because the glazing performance was lower with a U-value of $1.25 \mathrm{~W} / \mathrm{m}^{2} \mathrm{~K}$ in scenario 3 , a higher level of insulation on the exterior wall $(225 \mathrm{~mm})$ and roof $(175 \mathrm{~mm})$ was required in this scenario.

An energy demand comparison between the pre-retrofit case, EnerPHit requirement, baseline retrofit plan, and the improved retrofit plans are illustrated in Figure 9. Overall, the energy saving efficiency from the four improved retrofit plans was considered high, around $87 \%$ of heating energy and $70 \%$ of cooling energy were saved from the pre-retrofit situation. Though this energy saving efficiency was slightly lower than the baseline retrofit plan could provide, the amounts of insulation mass required in the improved plans were lower. As shown in Figure 9, the baseline retrofit plan required a total insulation mass of $165 \mathrm{~m}^{3}$ for the entire envelope, while about $18 \%, 36 \%, 44 \%$ and $58 \%$ of the insulation mass could be saved in each of the improved plans. A carbon factor of $1.31 \mathrm{kgCO}_{2} \mathrm{e} / \mathrm{kg}$ for Rockwool that had been produced in China was utilised to compare the carbon difference due to insulation material inputs in each retrofitting plan. As the results show in Figure 10, 21.6 tonnes of carbon emission would be released if the baseline retrofit plan was implemented, while by applying the four improved retrofit plans, carbon emissions would be reduced by 3.9, 7.9, 9.5 and 12.6 tonnes of carbon, respectively. However, the different amount of insulation mass and carbon savings depended on the assumption of the scenarios, which suggests that achieving a very low airtightness level and selecting good performance windows could significantly decrease the initial impact of retrofitting while attaining the EnerPHit standard energy saving efficiency. In addition, a significant carbon reduction in the building operational stage is expected from the improved retrofitting plans because satisfying energy saving results was evaluated in them. While the difference in carbon emissions from implementing the retrofitting measures in each improved plan should cause a different net carbon saving, to compare this, a life cycle carbon assessment for them, with more detail about the impact in each building life cycle and operating carbon under future weather conditions, is required.

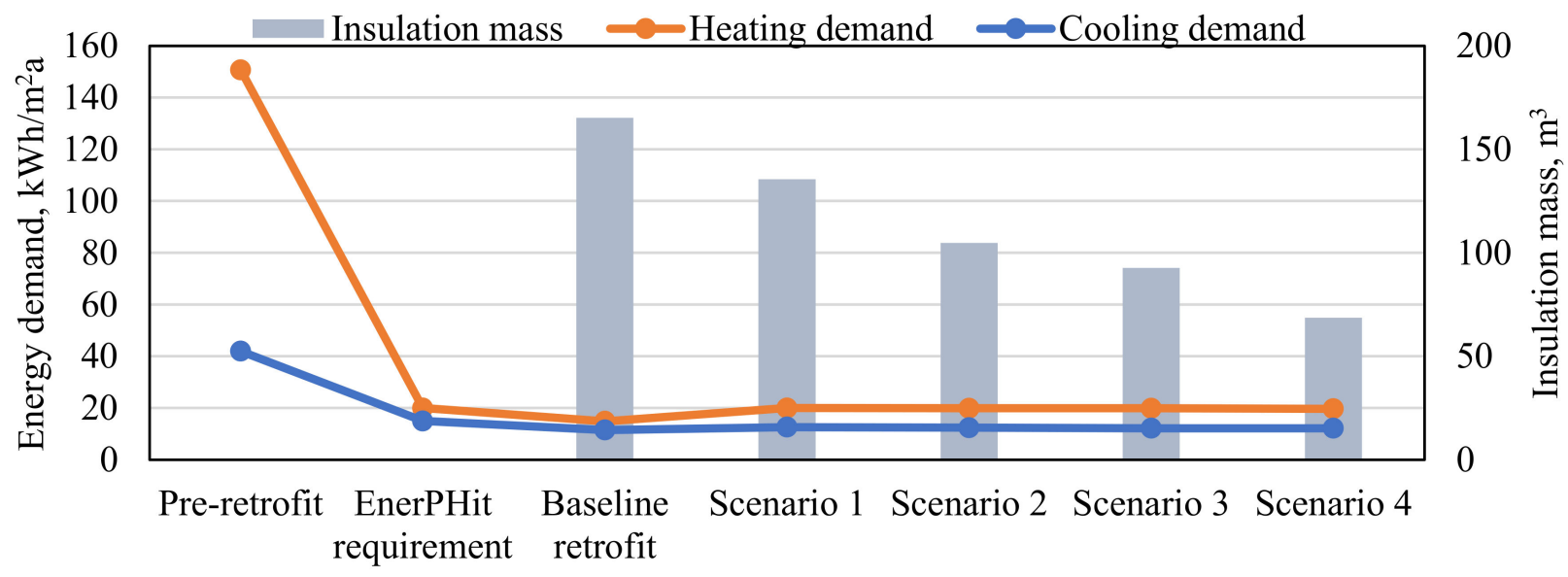

Figure 9. Comparing the energy demand between the pre-retrofit, baseline retrofit and improved retrofit plans against the EnerPHit standard requirement. 


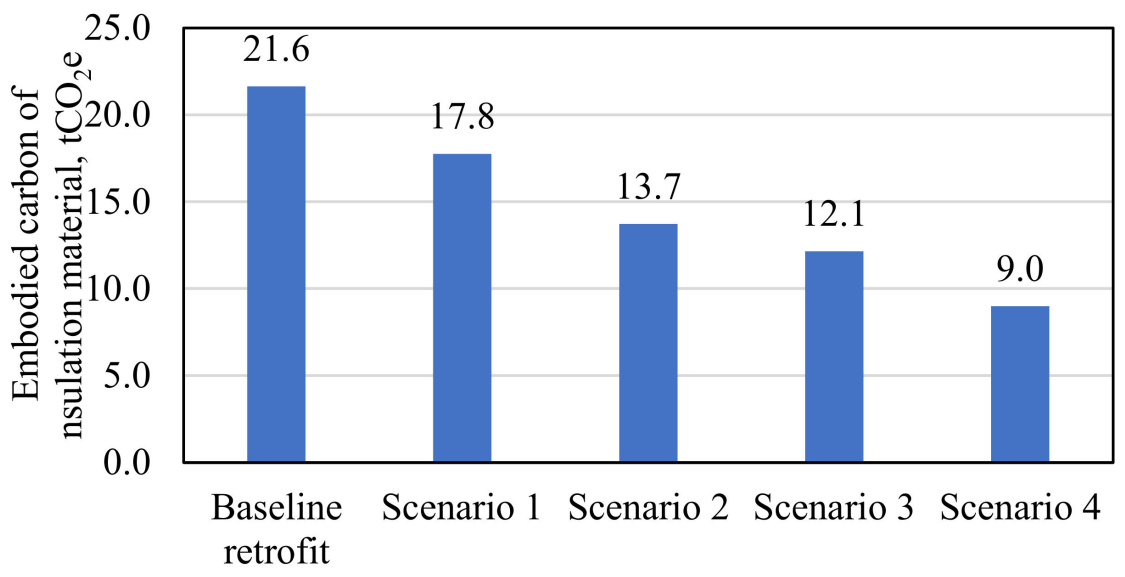

Figure 10. Carbon emission due to insulation material inputs in different retrofitting plans.

\section{Conclusions}

This paper considered the possibility of retrofitting plans which enable a case building to achieve the Passivhaus EnerPHit standard energy efficiency while the material inputs could be decreased against a baseline retrofit plan. The first finding from this research was that the heating demand should be the dominant factor to be considered in retrofitting under the hot summer-cold winter climate, because it was found to be much more sensitive to the envelope thermal performance changes than the cooling energy demand, and higher thermal performances from all the tested parameters were needed to achieve the EnerPHit heating criteria than the cooling criteria. As a result, the retrofitting solutions should have a high insulation thickness in the external wall, followed by the roof and floor, and the interior floors were confirmed unnecessary to be insulated. The final proposed retrofitting plans for the case building under the different scenarios could all achieve the EnerPHit standard with a very similar level of energy savings of about $87 \%$ and $70 \%$ in heating and cooling, respectively, from the pre-retrofit condition. However, the retrofitting material inputs for achieving this energy saving were different in each retrofitting plan. The main reason for this was the performance changes in airtightness level and windows, as the better performance of those two factors could lead to a lower required thickness in envelope insulation. Overall, due to the arrangement of the retrofitting measures, each proposed plan ultimately achieved insulation materials reduction, with reductions between $18 \%$ and $58 \%$ compared to the baseline retrofit plan, giving savings of 3.9 tonnes to 12.6 tonnes in carbon emissions.

In conclusion, the four retrofitting plans proposed in this study all achieved the EnerPHit standard with various reductions in retrofitting initial impacts when compared to the baseline retrofit plan. However, this study mainly focused on the energy point of view and the environmental impact was only analysed for the embodied carbon of the saved insulation material. A significant reduction in building operational carbon emission is expected from implementing the retrofitting plans due to the large operational energy savings. Future research should address this question with a detailed life cycle carbon assessment, in which a long building lifespan would be considered as well as the energy performance changes due to future climate change. Moreover, a life cycle cost analysis is also necessary for driving an inclusive retrofitting plan.

Author Contributions: Conceptualization, C.L., S.S. and H.M.; methodology, C.L.; software, C.L.; validation, S.S. and H.M.; formal analysis, C.L.; investigation, C.L.; resources, S.S. and H.M.; data curation, C.L.; writing—original draft preparation, C.L.; writing-review and editing, S.S. and H.M.; visualization, C.L.; supervision, S.S. and H.M. All authors have read and agreed to the published version of the manuscript.

Funding: This research received no external funding.

Institutional Review Board Statement: Not applicable. 
Informed Consent Statement: Not applicable.

Data Availability Statement: Data sharing is not applicable.

Conflicts of Interest: The authors declare no conflict of interest.

\section{References}

1. IEA. 2019 Global Status Report for Buildings and Construction; UN Enviroment Programme: Madrid, Spain, 2019. Available online: https:/ / www.iea.org/reports/world-energy-outlook-2019\%0Ahttps:/ /www.iea.org/reports/world-energy-outlook-2019\%0 Ahttps:/ / webstore.iea.org/download/summary/2467?fileName=Japanese-Summary-WEO2019.pdf (accessed on 28 August 2021).

2. Li, H.; Chen, B.; Feng, G. Investigation and Analysis on Present Situation of Existing Building Green Retrofitting in Public Institution. Procedia Eng. 2017, 205, 3340-3345. [CrossRef]

3. Liu, G.; Li, X.; Tan, Y.; Zhang, G. Building green retrofit in China: Policies, barriers and recommendations. Energy Policy 2020, $139,111356$. [CrossRef]

4. Baldwin, A.N.; Loveday, D.L.; Li, B.; Murray, M.; Yu, W. A research agenda for the retrofitting of residential buildings in China-A case study. Energy Policy 2018, 113, 41-51. [CrossRef]

5. CABEE. China Building Energy Research Report 2016, China Association of Building Energy Efficiency. 2016. Available online: http: / / www.efchina.org/Attachments/Report/report-20170710-1/report-20170710-1 (accessed on 24 September 2021).

6. CABEE. China Building Energy Research Report 2020. 2020. Available online: https://www.cabee.org/site/content/24020.html (accessed on 28 August 2021).

7. Wang, Z.; Zhao, Z.; Lin, B.; Zhu, Y.; Ouyang, Q. Residential heating energy consumption modeling through a bottom-up approach for China' s Hot Summer-Cold Winter climatic region. Energy Build. 2015, 109, 65-74. [CrossRef]

8. Ma, Z.; Cooper, P.; Daly, D.; Ledo, L. Existing building retrofits: Methodology and state-of-the-art. Energy Build. 2012, 55, 889-902. [CrossRef]

9. PHI. Criteria for the Passive House, EnerPHit and PHI Low Energy Building Standard. 2016. Available online: https:/ / passipedia. org/_media/picopen/9f_160815_phi_building_criteria_en.pdf (accessed on 13 April 2021).

10. Su, X.; Tian, S.; Shao, X.; Zhao, X. Embodied and operational energy and carbon emissions of passive building in HSCW zone in China: A case study. Energy Build. 2020, 222, 110090. [CrossRef]

11. Huang, H.; Binti Wan Mohd Nazi, W.I.; Yu, Y.; Wang, Y. Energy performance of a high-rise residential building retrofitted to passive building standard-A case study. Appl. Therm. Eng. 2020, 181, 115902. [CrossRef]

12. Liu, C.; Mohammadpourkarbasi, H.; Sharples, S. Evaluating the potential energy savings of retrofitting low-rise suburban dwellings towards the Passivhaus EnerPHit standard in a hot summer/cold winter region of China. Energy Build. 2021, 231, 110555. [CrossRef]

13. Schnieders, J.; Feist, W.; Rongen, L. Passive Houses for different climate zones. Energy Build. 2015, 105, 71-87. [CrossRef]

14. Wang, Y.; Kuckelkorn, J.; Zhao, F.Y.; Spliethoff, H.; Lang, W. A state of art of review on interactions between energy performance and indoor environment quality in Passive House buildings. Renew. Sustain. Energy Rev. 2017, 72, 1303-1319. [CrossRef]

15. Rohdin, P.; Molin, A.; Moshfegh, B. Experiences from nine passive houses in Sweden-Indoor thermal environment and energy use. Build. Environ. 2014, 71, 176-185. [CrossRef]

16. Ridley, I.; Clarke, A.; Bere, J.; Altamirano, H.; Lewis, S.; Durdev, M.; Farr, A. The monitored performance of the first new London dwelling certified to the Passive House standard. Energy Build. 2013, 63, 67-78. [CrossRef]

17. Kovacic, I.; Reisinger, J.; Honic, M. Life Cycle Assessment of embodied and operational energy for a passive housing block in Austria. Renew. Sustain. Energy Rev. 2018, 82, 1774-1786. [CrossRef]

18. Dalbem, R.; Grala da Cunha, E.; Vicente, R.; Figueiredo, A.; Oliveira, R.; da Silva, A.C.S.B. Optimisation of a social housing for south of Brazil: From basic performance standard to passive house concept. Energy 2019, 167, 1278-1296. [CrossRef]

19. Sui, J.; Meng, Y. Practice and Exploration of German Passive House in China Real Estate Project, Jiuzhang mansion by Poly group in Taizhou, Zhejiang. Low Carbon World 2019, 7, 163-164.

20. Karimpour, M.; Belusko, M.; Xing, K.; Bruno, F. Minimising the life cycle energy of buildings: Review and analysis. Build. Environ. 2014, 73, 106-114. [CrossRef]

21. Stephan, A.; Crawford, R.H.; de Myttenaere, K. A comprehensive assessment of the life cycle energy demand of passive houses. Appl. Energy 2013, 112, 23-34. [CrossRef]

22. Röck, M.; Saade, M.R.M.; Balouktsi, M.; Rasmussen, F.N.; Birgisdottir, H.; Frischknecht, R.; Habert, G.; Lützkendorf, T.; Passer, A. Embodied GHG emissions of buildings-The hidden challenge for effective climate change mitigation. Appl. Energy 2020, $258,114107$. [CrossRef]

23. Thormark, C. A low energy building in a life cycle-Its embodied energy, energy need for operation and recycling potential. Build. Environ. 2002, 37, 429-435. [CrossRef]

24. Sierra-Pérez, J.; Rodríguez-Soria, B.; Boschmonart-Rives, J.; Gabarrell, X. Integrated life cycle assessment and thermodynamic simulation of a public building's envelope renovation: Conventional vs. Passivhaus proposal. Appl. Energy 2018, 212, 1510-1521. [CrossRef]

25. Annibaldi, V.; Cucchiella, F.; De Berardinis, P.; Rotilio, M.; Stornelli, V. Environmental and economic benefits of optimal insulation thickness: A life-cycle cost analysis. Renew. Sustain. Energy Rev. 2019, 116, 109441. [CrossRef] 
26. Figueiredo, A.; Figueira, J.; Vicente, R.; Maio, R. Thermal comfort and energy performance: Sensitivity analysis to apply the Passive House concept to the Portuguese climate. Build. Environ. 2016, 103, 276-288. [CrossRef]

27. Badescu, V.; Sicre, B. Renewable energy for passive house heating: II. Model. Energy Build. 2003, 35, 1085-1096. [CrossRef]

28. Hsu, Y.S.; Zheng, X.; Cooper, E.; Gillott, M.; Wood, C.J. Evaluation of the indoor pressure distribution during building airtightness tests using the pulse and blower door methods. Build. Environ. 2021, 195, 107742. [CrossRef]

29. Erhorn-Kluttig, H.; Erhorn, H.; Lahmidi, H. Airtightness requirements for high performance building envelopes. EPBD Build. Platf. 2009, 157, 1-6.

30. MOHURD. Standard of Climatic Regionalization for Architecture (GB50178-93). 1993. Available online: http:/ /www.gd-sct.com/ uploadfile/file/20190222/20190222135232_650071809.pdf (accessed on 29 August 2021).

31. MOHURD. Design Standard for Energy Efficiency of Residential Building in Hunan Province DBJ 43/001-2017. 2017. Available online: http:/ / www.hunan.gov.cn/hnszf/xxgk/wjk/zcfgk/202007/t20200730_1eaa2d04-d44d-404b-a477-2a507744e8ba.html (accessed on 29 August 2021).

32. Garg, V.; Mathur, J.; Tetali, S.; Bhatia, A. Building Energy Simulation: A Workbook Using Designbuilder ${ }^{\mathrm{TM}}$; CRC Press: Boca Raton, FL, USA, 2017. [CrossRef]

33. Feist, W.; Schnieders, J.; Dorer, V.; Haas, A. Re-inventing air heating: Convenient and comfortable within the frame of the Passive House concept. Energy Build. 2005, 37, 1186-1203. [CrossRef]

34. Gasparella, A.; Pernigotto, G.; Cappelletti, F.; Romagnoni, P.; Baggio, P. Analysis and modelling of window and glazing systems energy performance for a well insulated residential building. Energy Build. 2011, 43, 1030-1037. [CrossRef]

35. Sigalingging, R.C.; Chow, D.; Sharples, S. Modelling the impact of ground temperature and ground insulation on cooling energy use in a tropical house constructed to the Passivhaus Standard. In Earth and Environmental Science, Proceedings of the Sustainable Built Environment Conference, Cardiff, UK, 24 -25 September 2019; IOP Conference Series; IOP Publishing: Bristol, UK, 2019; Volume 329, p. 012010. [CrossRef] 